\title{
PURIFICATION OF PHARMACEUTICAL WASTE WATER RESULTING FROM HERBAL PLANTS BY ZERO LIQUID DISCHARGE TECHNIQUES (ZLD)
}

\author{
Nancey Hafez, Faculty of ecology, National aviation university, Ukraine
}

DOI: https://doi.org/10.31435/rsglobal_conf/30052021/7582

Abstract. Introduction. Zero liquid discharge (ZLD)is advanced water treatment process technology that remove waste water product economically and produce clean water for reuse e.g. irrigation. this water treatment process is money saving, environmentally friendly and highly trustable. zero liquid technology (ZLD) is the most effective solution for obtaining strict environmental discharge standards and produce water treatment recovery with lowest possible cost. ZLD help in recovering materials from the waste water streams e.g. potassium sulfate, soda, sodium sulfate and lithium.

ZLD treatment system should be: Convenient to large scale of waste contaminations. This treatment recover $95 \%$ of liquid waste for reuse. Can produce dry solid disposal. Can be separate by product from waste. Help to adjusting chemical volumes.

Purpose. Used treated waste water as Cooling towers industry. Boiler water for generating steam for MEE. Used in water scrubbers as scrub media. Prepare of lime slurry for ETP. Various operations of industrial washings.

Keywords: Zld, UF, Ro, MEE, MVR, pharmaceutical waste waters treatment.

Methods. ZID treatment process steps:

Pretreatment it is should be remove simple contaminants from waste water stream by filtration or precipitation out.

The treatment consists of clarifier or a reactor to precipitate out metals, hardness and silica. This step require caustic soda or lime for coagulation. This step require add chemicals and one or two reactors to settle down the small particles from water.

Using coagulates contains aluminum with slight $\mathrm{PH}$ adjustment when coagulation is complete the water enters a flocculation chamber followed by sedimentation part of ZLD process.

Where the water rises to the top and allowing solids to settle down into sludge blanket.

Ultra filteration can also used which pump water directly from waste water through UF (chlorination) and eliminate the clarifier/filteration.

Concentration in ZLD is usually performed by (RO)reverse osmosis, brine concentrator or electrodialysis or combined together.

They are used to remove dissolved solids waste and to obtain pretreated water.

RO has a tight pore structure (membrane used less than 0.001 micron) that effectively removes up to $99 \%$ of the dissolved salts (ions) particles, colloids, organics, bacteria and pathogens from the water [7].

Evaporation / crystallization:

After concentration steps is completed then followed by next step of generating solids by thermal process or evaporatation, which lead to evaporate all water off and reuse it. This is Can be done by adding acid which neutralize the solution and. also can perform dear ration at this step to release dissolved oxygen, carbon dioxide and other gases. the leftd waste go then from evaporator to a crystallizer which continues to boil off all the water where all waste presented in the water crystallized and turned to solids.

\section{Results:}

ZLD system depend on thermal and evaporative process e.g multi stage flash (MSF), multi effect distillation (MED), mechanical vapor compression (MCV) and crystallizers. Evaporations and crystallizations system capacity range from around $10 \mathrm{gpm}$ to $1500 \mathrm{gpm}$ per units. Falling film evaporators called brine concentrators are technology for heat transfer which produce high pure distillation and water recovery greater that $90 \%$ recovered water in a brine water concentrator is 
suitable as cooling tower or scrubbing media and can be recycled to other plant process including demineralization of water. this waste water evaporators can be acted by mechanical vapor decompression (MVR) or with other stream depending on the costs of electric power and steam.crystallizes are used to handle crystallization of the dissolved salts which can be recovered as by products. waste water crystallizes are used to concentrate the effluent from brine concentrators when equipped with dry solid comprise zero liquid discharge system. this brine crystallizes are acted by live steam or MVR technology to recycle the vapor and this can help in reducing energy use and costs.

The wastewater is analyzed for the major water quality parameters, such as $\mathrm{pH}$, Biological Oxygen Demand (BOD), Chemical Oxygen Demand (COD) and Total Dissolved Solids (TDS). The effluent samples were collected on a daily basis for a period of one month. The raw wastewater $\mathrm{pH}$ was highly alkaline it was then bringing down to neutral which was helpful for biological treatment. The BOD, COD of the treated effluent reduced significantly, where as very small reduction was observed in dissolved solids.

Transformation of COD into organics and TDS (total dissolved solid) into dry salts for disposal by zero liquid discharge treatment system [5].

In zero liquid discharge system the overall loads reduction was 99.2 percent in TDS, 99.9 percent in COD and 100 percent in both the TSS and BOD. By the various experimental analysis relieving that the designed ZLD unit can be used effectively to treat and recycle API manufacturing unit effluents, which helps to meet statutory requirements and reduce concerns on ground water depletion.

By the experimental studied MEE (Multiple Effective Evaporator), ATFD (Agitated Thin Film Drier) and LCS effluent treatment unit made of a SBR (Sequential Batch Reactor) and MBR (Membrane Bio-Reactor) with other unit which is called as water recycling unit consisting RO (Reverse Osmosis) plant the pilot plant of ZLD shown a huge reduction in TDS (Total Dissolved Solids), TSS (Total Suspended Solids), BOD (Biological Oxygen Demand) and TSS (Total Suspended Solid) to 99.2, 100, 100 and 99.9 percent respectively [9]. ZLD Reduce your carbon which eliminates liquid waste by converting it into disposable dry solids by application of powdered activated carbon and by reverse osmosis almost $50 \%$ total organic carbon (TOC)removal removal takes place during coagulation lime softening process include using of powdered activated carbon.

Table 1. Table of ZLD process.

\begin{tabular}{|c|c|c|c|c|}
\hline $\begin{array}{l}\text { ZLD } \\
\text { Technology }\end{array}$ & Use & Advantages & Disadvantages & Application \\
\hline $\begin{array}{l}\text { Membrane Bio } \\
\text { Reactor (MBR) }\end{array}$ & $\begin{array}{l}\text { Used as biological } \\
\text { secondary treatment } \\
\text { for reduction of organic } \\
\text { load. }\end{array}$ & $\begin{array}{l}\text { Treated water quality is better than } \\
\text { conventional ASP, MBBR and SBR. } \\
\text { Post treatment of sand filtration not } \\
\text { required. }\end{array}$ & $\begin{array}{l}\text { Capital cost is more than } \\
\text { other aerobic biological } \\
\text { technologies (ASP, SBR, MBBR). }\end{array}$ & $\begin{array}{l}\text { CETPs } \\
\text { Oil Refineries } \\
\text { Fertilizer Industry }\end{array}$ \\
\hline $\begin{array}{l}\text { Solvent } \\
\text { recovery-Air } \\
\text { Stripper }\end{array}$ & $\begin{array}{l}\text { Used for recovering } \\
\text { solvents/ammonia } \\
\text { recovery by providing air. }\end{array}$ & $\begin{array}{l}\text { Economical when solvents with low } \\
\text { solubility in water are present in } \\
\text { wastewater. }\end{array}$ & $\begin{array}{l}\text { Applicable only when large } \\
\text { quantity of solvent with low } \\
\text { solubility in water is present in } \\
\text { wastewater. }\end{array}$ & $\begin{array}{l}\text { Recovery of useful } \\
\text { solvents, ammonia } \\
\text { in pharmaceutical } \\
\text { industry } \\
\text { Pesticide Industry } \\
\text { Chemical Industry }\end{array}$ \\
\hline $\begin{array}{l}\text { Solvent } \\
\text { Recovery - } \\
\text { Steam Stripper }\end{array}$ & $\begin{array}{l}\text { Used for recovering } \\
\text { solvents by using steam. }\end{array}$ & $\begin{array}{l}\text { Useful even less quantity of solvent } \\
\text { present in wastewater }\end{array}$ & $\begin{array}{l}\text { Scaling occurs in column which } \\
\text { is to be cleaned periodically. }\end{array}$ & $\begin{array}{l}\text { Recovery of useful } \\
\text { solvents, ammonia } \\
\text { in pharmaceutical } \\
\text { industry }\end{array}$ \\
\hline
\end{tabular}


Continuation of table 1

\begin{tabular}{|c|c|c|c|c|}
\hline $\begin{array}{l}\text { ZLD } \\
\text { Technology }\end{array}$ & Use & Advantages & Disadvantages & Application \\
\hline $\begin{array}{l}\text { Ultra Filtration } \\
\text { (UF) }\end{array}$ & $\begin{array}{l}\text { Used for removal of } \\
\text { colloidal matter and } \\
\text { bacteria and viruses. } \\
\text { Used as pre-treatment } \\
\text { to RO. }\end{array}$ & $\begin{array}{l}\text { Removes suspended, colloidal } \\
\text { particles, bacteria, viruses. }\end{array}$ & $\begin{array}{l}\text { Does not filter dissolved solids, } \\
\text { gases and organics. Frequent } \\
\text { backwash, membrane cleaning. } \\
\text { Replacement of membranes } \\
\text { after } 5 \text { years required. }\end{array}$ & $\begin{array}{l}\text { Pre-treatment } \\
\text { to } R O \text { in all ZLD } \\
\text { plants. }\end{array}$ \\
\hline $\begin{array}{l}\text { Reverse } \\
\text { Osmosis (RO) }\end{array}$ & $\begin{array}{l}\text { Used for removal of } \\
\text { salinity (TDS) and } \\
\text { residual organics by } \\
\text { passing wastewater } \\
\text { through semi-permeable } \\
\text { membrane by applying } \\
\text { high pressure. }\end{array}$ & $\begin{array}{l}\text { Most effective treatment for removal } \\
\text { of salinity (TDS) with more than } 99 \% \\
\text { salt rejection. } \\
\text { Clean technology and no handling } \\
\text { of chemicals like acid/alkali like ion } \\
\text { exchange technology. }\end{array}$ & $\begin{array}{l}\text { Cleaning of membrane } \\
\text { frequently due to membrane } \\
\text { fouling } \\
\text { Reject Water }\end{array}$ & $\begin{array}{l}\text { Used in all industrial } \\
\text { sectors for TDS } \\
\text { removal and } \\
\text { recycling the water. }\end{array}$ \\
\hline $\begin{array}{l}\text { Multiple Effect } \\
\text { Evaporator } \\
\text { (MEE) }\end{array}$ & $\begin{array}{l}\text { Used to evaporate } \\
\text { wastewater to separate } \\
\text { water and salt by } \\
\text { using heat of steam in } \\
\text { sequence of vessels. }\end{array}$ & $\begin{array}{l}\text { Proven method for recovery of water } \\
\text { from saline water and separation of } \\
\text { salt. }\end{array}$ & $\begin{array}{l}\text { Very high operating cost due } \\
\text { to steam requirement. }\end{array}$ & $\begin{array}{l}\text { Pharmaceutical } \\
\text { Industry, Textile } \\
\text { Industry, Pesticide } \\
\text { Industry, Dyes and } \\
\text { Dye Intermediates, } \\
\text { Steel Industry, } \\
\text { Fertilizer Industry }\end{array}$ \\
\hline $\begin{array}{l}\text { Mechanical } \\
\text { Vacuum } \\
\text { Compressor } \\
\text { (MVR) }\end{array}$ & $\begin{array}{l}\text { Water vapour generated } \\
\text { in the evaporator is } \\
\text { compressed to higher } \\
\text { pressure which acts } \\
\text { as heat source for } \\
\text { evaporation. }\end{array}$ & $\begin{array}{l}\text { Useful when steam not available. } \\
\text { Low operating cost. }\end{array}$ & $\begin{array}{l}\text { Suitable only for liquid with } \\
\text { narrow boiling point rise } \\
\text { (BPR). }\end{array}$ & Textile Industry \\
\hline Crystallizer & $\begin{array}{l}\text { Used to dry high TDS } \\
\text { water or products using } \\
\text { heat. }\end{array}$ & $\begin{array}{l}\text { Used for recovery of salts like Sodium } \\
\text { Sulphate, Sodium Chloride, Sodium } \\
\text { Thiosulphate, Zinc Sulphate etc. } \\
\text { Simple Evaporation method of single } \\
\text { effect evaporation. }\end{array}$ & $\begin{array}{l}\text { Scaling and corrosion of unit is } \\
\text { a problem. }\end{array}$ & $\begin{array}{l}\text { All industrial } \\
\text { sectors. }\end{array}$ \\
\hline $\begin{array}{l}\text { Agitated Thin } \\
\text { Film Dryer } \\
\text { (ATFD) }\end{array}$ & $\begin{array}{l}\text { Used to dry high TDS } \\
\text { water or products using } \\
\text { fast revolving rotor in a } \\
\text { heating jacket. }\end{array}$ & $\begin{array}{l}\text { Gentle evaporation and high } \\
\text { evaporation rate. } \\
\text { Continuous cleaning of heating } \\
\text { surface. } \\
\text { One passes Evaporation. }\end{array}$ & $\begin{array}{l}\text { Scaling and corrosion of unit is } \\
\text { a problem. }\end{array}$ & $\begin{array}{l}\text { Textile Industry } \\
\text { Pharmaceutical } \\
\text { Industry for final } \\
\text { drying before } \\
\text { disposal. }\end{array}$ \\
\hline \multirow{3}{*}{ Incinerator } & \multirow{3}{*}{$\begin{array}{l}\text { Used for burning the } \\
\text { concentrated effluent by } \\
\text { thermal energy }\end{array}$} & \multirow{3}{*}{$\begin{array}{l}\text { Useful method for very high strength } \\
\text { (High COD) effluent which is difficult } \\
\text { to biodegrade. No further treatment } \\
\text { is required. }\end{array}$} & Requires very high energy. & $\begin{array}{l}\text { Pharmaceutical } \\
\text { Industry }\end{array}$ \\
\hline & & & $\begin{array}{l}\text { Operational cost is high. } \\
\text { Capital cost is high. }\end{array}$ & $\begin{array}{l}\text { Dye and Dye } \\
\text { Intermediates } \\
\text { Pesticide Industry }\end{array}$ \\
\hline & & & $\begin{array}{l}\text { Viable for only small quantities } \\
\text { of effluent. }\end{array}$ & \\
\hline
\end{tabular}


Table 2. Table of Sector wise of ZLD treatment options for industries.

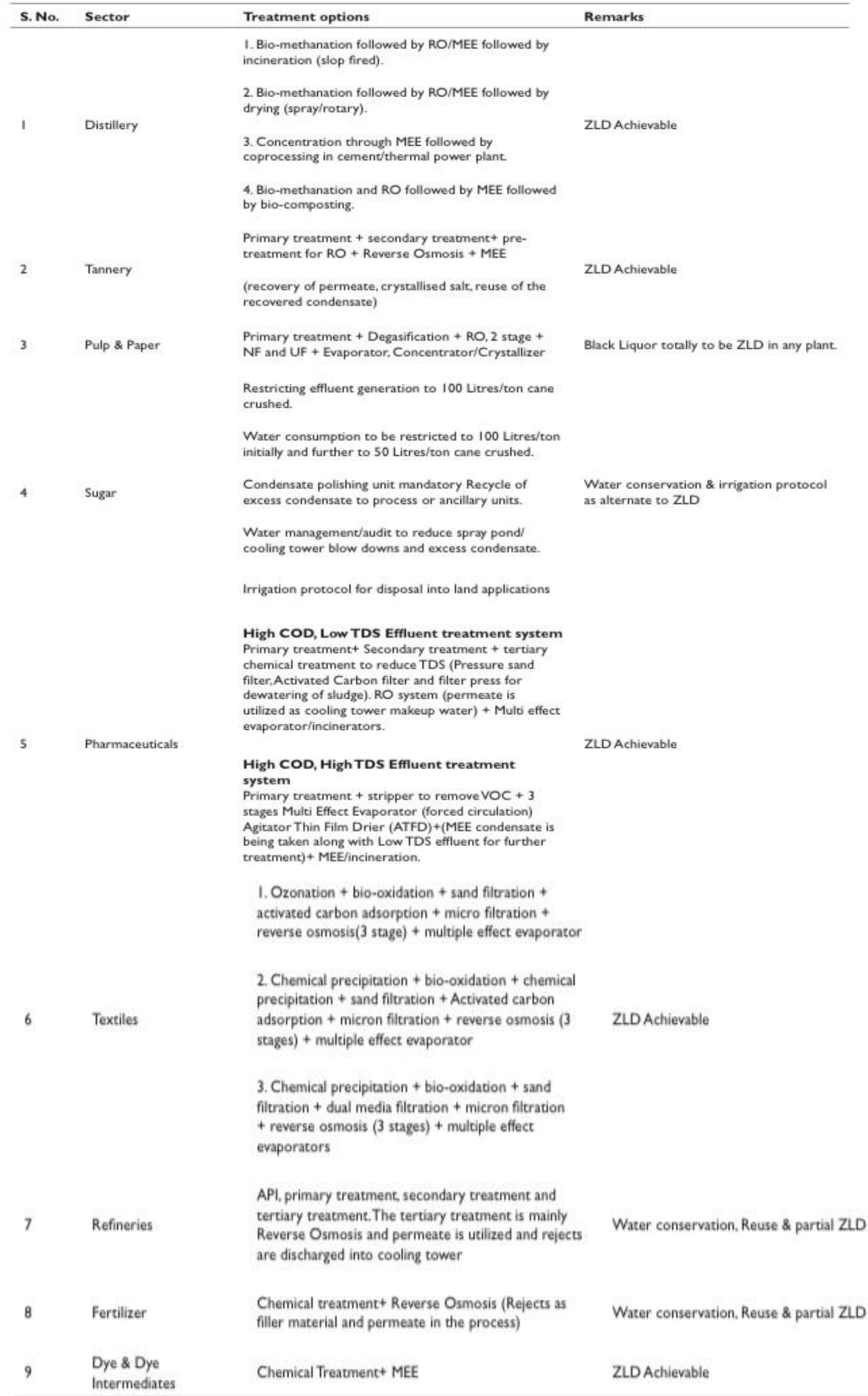


Conclusions. ZLD had a high successful process for waste water industry treatment which minimize the high toxicity, $\mathrm{PH}$, organic pollutants and resources of recovery. the consumption of water that generated from ZLD systems able to recycle in plant premises which reduce use of water and decrease waste pollutions and maximize water resources. ZLD carried out by systematic waste water control strategy consists of coagulation, UF, RO, aeration system, etc.

Although the high capability of ZLD systems in industrials scales but it has a limited use due to increased energy consumptions and their costs.

\section{REFERENCES}

1. Rappich O. The rising industrial adoption of zero liquid discharge. Water world; 2016. Copyright: 10 (C)2020 Rathoure

2. Yusuf M. Handbook of textile effluent remediation. Pan Stanford Publishing; 2018. 434 p.

3. Jordan A. Zero liquid discharge options. Water world; 2009.

4. GPCB. Zero liquid discharge (ZLD) technology guidance manual. 2016.

5. Vishnu G, Palanisamy S, Joseph K. Assessment of field scale zero liquid discharge treatment systems for recovery of water and salt from textile effluents. Journal of Cleaner Production. 2008;16(10):1081-1089.

6. Tong T, Elimelech M. The global rise of zero liquid discharge for wastewater management: drivers, technologies, and future directions. Environmental Science \& Technology. 2016; 50:13.

7. Saha I. Zero liquid discharge: treating effluents as a resource stream instead of waste stream is the way forward. 2014.

8. Ahirrao S. Zero Liquid discharge solutions. Industrial wastewater treatment, recycling and reuse. Butterworth-Heinemann; 2014:489-20. 